${ }^{1}$ Health center «ORS Hospital» Belgrade

${ }^{2}$ General hospital Doboj

${ }^{3} I K V B \ll$ Dedinje» Belgrade

${ }^{4}$ FZORS Banja Luka

${ }^{5}$ General hospital Prijedor

\title{
THE ANALYSIS OF INFLUENCE OF TUMOR LOCALIZATION ON LATE DIAGNOSIS AND TREATMENT IN PATIENTS WITH SKIN MELANOMA
}

\section{ANALIZA UTUCAJA LOKALIZACIJE TUMORA NA KASNU DIJAGNOZU I LEČENJE PACIJENATA SA MELANOM KOŽE}

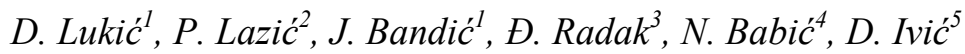

\section{Summary}

With the prospective study, from June 2004 to June 2012, were compared the results of the influence of tumor position on late diagnosis and treatment of skin melanoma. Respondents were classified according to clinical appearance in 2 equal groups. The first group, group A (32 respondents) consisted of respondents that underwent radical wide excision of the primary tumor at an early stage of the disease. In the second group, group B (32 respondents) were classified respondents with melanoma that underwent radical excision of melanoma at a later stage of the disease.

The aim of this study was to analyze the influence of tumor localization on late diagnosis and treatment of skin melanoma.

In 25 respondents (78.1\%) who were operated at an early stage, melanoma was located on the face, chest, abdomen and extremities, while in 7 (21.9\%) respondents, melanoma was localized on the back. In the group of late operated respondents, melanoma was positioned on the face, chest, abdomen and extremities in $9(28.1 \%)$ respondents, while in 23 (71.9\%) respondents, tumor was localized on the back.

It has been shown that tumor localization essentially determines the time of visits of respondents for examination.

Melanoma on the back remains unnoticed for a long time, i.e. unrecognized changes in lesions compared to lesions of other anatomical regions, which is probably the reason for the bigger waste of time and late diagnosis.

Respondents in group B consulted the doctor 4-5 months later, because of melanoma position than the group A, which is proved to be statistically significant.
There was found a statistically significant difference in terms of recurrence of the disease. Relapse was observed in group $B 3$ times higher than in group A.

Localization of melanoma significantly affects the outcome of the treatment of the disease. There was a statistically significant difference in survival of respondents in groups, because the mortality rate in group $B$ was almost three times higher.

Key words: skin, melanoma, late diagnosis

\section{Sažetak}

Prospektvnom studijom $u$ periodu od juna 2004.do juna 2012. godine, upoređivani su rezultati uticaja pozicije tumora na kasnu dijagnozu i lečenje melanoma kože. Ispitanici su prema kliničkom izgledu svrstani u 2 jednake grupe. Prvu, grupu A (32 ispitanika), činili su ispitanici kojima je urađena radikalna široka ekscizija primarnog tumora u ranoj fazi obolenja. U drugu, grupu B (32 ispitanika), svrstani su ispitanici sa melanomom kojim je rađena radikalna ekscizija melanoma u kasnijoj fazi oboljenja. Cilj rada bio je analiza uticaja lokalizacije tumora na kasnu dijagnozu i liječenje melanoma kože.

Kod $25(78,1 \%)$ rano operisanih ispitanika melanom je bio lokalizovan na licu, grudima, trbuhu $i$ ekstremitetima dok je kod 7 (21,9\%) melanom bio lokalizovan na leđima. U grupi kasno operisanih ispitanika melanom je bio pozicioniran na na licu, grudima, trbuhu $i$ ekstremitetima kod 9 (28,1\%) ispitanika, dok je kod 23 (71,9\%) tumor bio lokalizovan na leđima.

Pokazalo se da lokalizacija tumora bitno određuje vrijeme javljanja ispitanika na pregled.

Melanom na leđima duže vrijeme ostaje nezapažen, odnosno, ostanu nezapažene promjene na leziji $u$ odnosu na lezije drugih anatomskih regija, što je 
vjerovatno razlog za veći gubitak vremena i kasnu dijagnozu.

Ispitanici grupe B su se radi pozicije melanoma javljali na pregled 4-5 mjeseci kasnije od ispitanika grupe A što se pokazalo statistički značajnim.

Promađena je značajna statistička razlika u pogledu recidiva oboljenja. Recidiv je u grupi $B$ zabilježen 3 puta češce u odnosu na grupu A.

Lokalizacija melanoma značajno utiče na ishod liječenja oboljenja. Utvrđena je značajna statistička razlika u preživljavanju ispitanika po grupama jer je smrtnost u grupi B bila skoro 3 puta češća.

Ključne riječi: koža, melanom, kasna dijagnoza

\section{Introduction}

Regardless of the fact whether melanoma arises from alteration of moles or is a primary malignant form, timely diagnosis is of the utmost importance. 1,2 Melanoma may, if it is congenital, for years remain idle and so offers possibility of timely diagnosis. 3 During the phase 'in situ', when the skin melanoma is thinner than $1 \mathrm{~mm}$, there is a real possibility to cure this disease. 4,5

So far, there were published several studies that evaluated the accuracy of the clinical diagnosis in the diagnostics of malignant melanocytic skin lesions and, depending on the author, the percentage ranges from $65-80 \% .1-4$

Until the advent of dermoscopy, melanoma was diagnosed by chance or on the basis of histopathological analysis after removing some of the pigmented skin lesions, or on the basis of the clinical examination. 5-8

Successful treatment of melanoma is based on early diagnosis and radical surgical excision. Radical surgical removal is a sacrosanct basis for successful treatment. In melanomas with great possibilities for metastasis, after surgical treatment, adjuvant therapy is applied. 5-9,10

There are a number of medicaments used in the treatment of melanoma ranging from biologic therapy, activator of macrophages, chemotherapy, and biochemotherapy and melanoma vaccines. The introduction of these drugs into therapy is defined by a protocol for treatment of melanoma after radical surgical removal. 5-9,11

\section{Goal}

The aim of this study was analysis of the influence of tumor localization on late diagnosis and treatment of skin melanoma.

\section{Materials and methods}

With the prospective study, from June 2004 to June 2012, were compared the results of the diagnosis and treatment of skin melanoma. Respondents were classified according to clinical appearance in 2 equal groups. The first group, group A (32 respondents) consisted of respondents that underwent radical wide excision of the primary tumor at an early stage of the disease. In the second group, group B (32 respondents) were classified respondents with melanoma that underwent radical excision of melanoma at later stage of the disease.

There was analyzed the time distance from the occurrence of changes in pigmented lesions (changes in color, edge, diameter, symmetry) until coming to the computer dermoscopy, i.e., the time from the appearance of symptoms in a suspicious change (pain, itching, bleeding) until coming to examination.

At the same time, the period of recurrence and 5year survival in patients in both groups was measured.

They were followed postoperatively by clinical examination, blood analysis (LDH) and EHO of abdomen and regional lymphatics every 6 months for 3 years, then annually for 4 and 5 years.

\section{Table 1. Respondents by gender}

\begin{tabular}{|l|l|l|}
\hline Gender & Group A & Group B \\
\hline Male & $15(46.8 \%)$ & $19(59.3 \%)$ \\
\hline Female & $17(53.2 \%)$ & $13(49.7 \%)$ \\
\hline Total & $32(100 \%)$ & $32(100 \%)$ \\
\hline
\end{tabular}

Table 2. Respondents by age

\begin{tabular}{|l|l|l|}
\hline Age & Group A & Group B \\
\hline $20-30$ & $3(9.4 \%)$ & $2(6.3 \%)$ \\
\hline $30-40$ & $8(26 \%)$ & $5(15.6 \%)$ \\
\hline $40-50$ & $7(21.8 \%)$ & $11(34.3 \%)$ \\
\hline $50-60$ & $6(18.7 \%)$ & $10(31.3 \%)$ \\
\hline $\begin{array}{l}\text { Over } \\
60\end{array}$ & $8(25 \%)$ & $4(12.5 \%)$ \\
\hline Total & $32(100 \%)$ & $32(100 \%)$ \\
\hline
\end{tabular}

Table 3. The distribution of respondents according to thickness of melanoma (Breslow)

\begin{tabular}{|l|l|l|}
\hline $\begin{array}{l}\text { Thickness of } \\
\text { melanoma } \\
\text { Breslow }\end{array}$ & Group A & Group B \\
\hline$<1.2 \mathrm{~mm}$ & $0(0 \%)$ & $2(6.3 \%)$ \\
\hline $1.2-2 \mathrm{~mm}$ & $11(34.3 \%)$ & $5(15.5 \%)$ \\
\hline $2-3 \mathrm{~mm}$ & $13(40.7 \%)$ & $12(37.5 \%)$ \\
\hline $3-4 \mathrm{~mm}$ & $8(25 \%)$ & $13(49.7 \%)$ \\
\hline Total & $32(100 \%)$ & $32(100 \%)$ \\
\hline
\end{tabular}

\section{Results}

The research results are presented in Tables 4-7 and Figure 1-2. Parameters for comparison of the 
results were: time elapsed from occurrence of change in lesion until examination, localization of melanoma, melanoma relapse and survival.

Table 4. Time elapsed from occurrence of change in lesion until examination

\begin{tabular}{|l|l|l|}
\hline Time/months & Group A & Group B \\
\hline $1-2$ & $19(59.3 \%)$ & $2(6.3 \%)$ \\
\hline $3-4$ & $7(21.8 \%)$ & $6(18.7 \%)$ \\
\hline $5-6$ & $4(12.5 \%)$ & $13(40.7 \%)$ \\
\hline $7-12$ & $1(3.2 \%)$ & $8(25 \%)$ \\
\hline Over 12 & $1(3.2 \%)$ & $3(9.3 \%)$ \\
\hline Total & $32(100 \%)$ & $32(100 \%)$ \\
\hline
\end{tabular}

Table 5. Localization of melanoma

\begin{tabular}{|l|l|l|}
\hline Localization & Group A & Group B \\
\hline $\begin{array}{l}\text { Head, chest, } \\
\text { abdomen, } \\
\text { extremities }\end{array}$ & $25(78.1 \%)$ & $10(31.3 \%)$ \\
\hline Back & $7(21.9 \%)$ & $22(68.1 \%)$ \\
\hline Total & $32(100 \%)$ & $32(100 \%)$ \\
\hline
\end{tabular}

Table 6. Relapse of melanoma

\begin{tabular}{|l|l|l|}
\hline Relapse & Group A & Group B \\
\hline Yes & $4(12.5 \%)$ & $13(40.7 \%)$ \\
\hline No & $28(87.5 \%)$ & $19(59.3 \%)$ \\
\hline Total & $32(100 \%)$ & $32(100 \%)$ \\
\hline
\end{tabular}

Figure 1. Relapse of melanoma

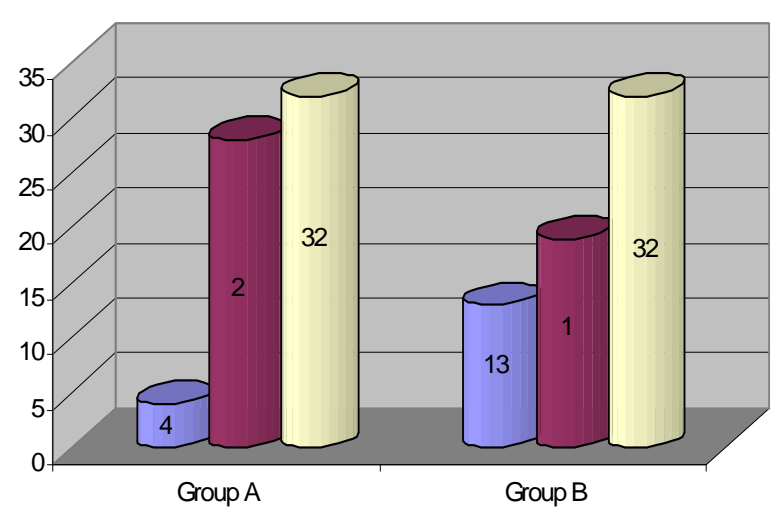

Table 7. Survival

\begin{tabular}{|l|l|l|}
\hline Survival & Group A & Group B \\
\hline $\begin{array}{l}5 \text { years without } \\
\text { relapse }\end{array}$ & $29(90.6 \%)$ & $24(75 \%)$ \\
\hline Lethal & $3(9.3 \%)$ & $8(25 \%)$ \\
\hline Total & $32(100 \%)$ & $32(100 \%)$ \\
\hline
\end{tabular}

Figure 2. Survival

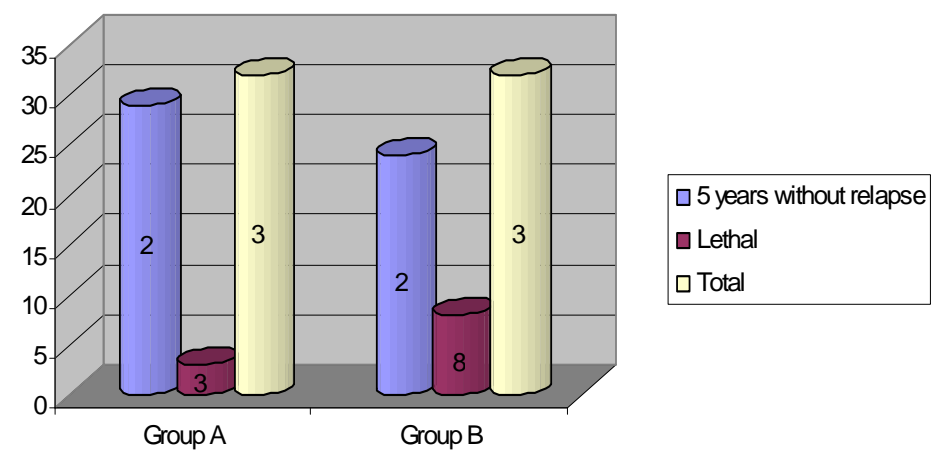

Statistical analysis of differences between groups $\mathrm{A}$ and $\mathrm{B}$ reveals the following:

There is a statistically significant difference between group A and group B, in terms of characteristics of the time of arrival at the examination ( $p<0.01,99 \%$ confidence),$Z=2.22351$

There is a statistically significant difference between group $\mathrm{A}$ and group $\mathrm{B}$, in terms of localization ( $p<0.01,99 \%$ confidence), $Z=372.911$

There is a statistically significant difference between group A and group B, in terms of characteristics of relapse ( $p<0.01,99 \%$ confidence), $\mathrm{Z}$ $=2.02883$

There is a statistically significant difference between group $\mathrm{A}$ and group $\mathrm{B}$, in terms of characteristics of a lethal outcome ( $p<0.01,99 \%$ confidence), $\mathrm{Z}=2.648265$

\section{Discussion}

In 1838 , Norris described melanoma as a change in the skin, mostly black, but more often colorful, with asymmetrical edges, sometimes with local satellites. He concluded that the melanoma tends to spread in visceral organs, and that in the case of delayed diagnosis, the stage of disseminated disease, there is no effective therapy.2

Melanomas are tumors, whose behavior is difficult to predict. 3 Melanomas may often be able to remain "idle" for many years. 2,3 Some of them are highly malignant with the worst prognosis, while others, with similar histology can behave relatively benign. There are many disagreements about the mutual relation of pigmented nevi and melanomas.4,5 Congenital melanocytic changes or those that are remembered from childhood often are places where malignant alteration longer remains underdiagnosed. The changes that have occurred "de novo" draw more attention to it. 6

Despite the fact that the pigment changes in the skin are usually obvious, the diagnosis of melanoma is often very difficult. 2-7 Timely, accurate diagnosis is the only chance to cure melanoma. 3-6 Wrong clinical evaluation of malignant pigmented lesion that is 
benign, resulting in a situation where the patient loses valuable time and a chance for cure. The main problem lies in the mimicry character of melanoma that for long can make it look like a harmless nevus.

Although melanoma can be amelanotic, the most common diagnostic problem is the differentiation dysplasion moles from melanoma. 2-7,8,9,10

Introduction of dermoscopy into the diagnostics of skin cancer, there is a possibility, not only of precise clinical diagnosis, but also of differentiation of melanocytic from nonmelanocytic skin lesions and then to differentiate benign from malignant melanocytic skin lesions. 4-7

Most of our respondents 39 (60.1\%) stated that suspected pigmented lesion (melanoma), they had since birth, which is less likely. This claim seems to be the result of the rationalization of the problem in the area of prejudice, that the changes existing from birth are harmless.

In our respondents in group A, the most common period for arrival to examination was a period of 1-2 months, after the change had been noticed in pigmented lesion, while in group Bit was a period of 56 months. Respondents in group B, because of frequent localization of melanoma on the back, a lesion simply not noticed, i.e., they noticed it later or not noticed a change in the lesion.

Our respondents from group A most often came to examination when they noticed a change in color, size and shape of pigmented lesions. Respondents from group B most often came to examination after noticing bleeding from pigmented lesion.

Predilection sites for the development of melanoma are debatable. Patients of African descent tend to have melanoma on feet and legs. In north Europe (e.g. Denmark) women have melanoma three times more in the lumbar region than men, and five times greater incidence of melanoma on the lower legs, while the incidence of melanoma on foot is the same in both gender. Localization of melanoma in people of Japanese islands is more common on the feet and covered parts of body.11-16

Most of the analyses in our region confirm the frequent localization of malignant melanoma on the skin back and chests in men, and on extremities in women, but the global analysis of positioning melanoma suggesting that virtually there is no anatomical region that is "safe", regardless of whether they are covered or uncovered parts of the body. 5

We recorded in our respondents a dominant position of melanoma on back and that in $30(46.8 \%)$ respondents in both groups. In all other regions together (head, chest, limbs), melanoma was positioned in $34(53.1 \%)$ respondents of groups A and B.

In our respondents in group A, melanoma was often positioned on the anterior anatomical regions. Only $7(21.9 \%)$ respondents in group A had a melanoma on back, which was statistically significant different in terms of the number of melanoma of back skin in group B.

According to Breslow, the percentage of patients with relapses or metastasis in postoperative period of five years, in stage I of disease (melanoma $<0.76 \mathrm{~mm}$ ) is $0 \%$, in stage II $(0.76$ to $1.5 \mathrm{~mm})$ is $33 \%$, in stage III ( 1.5 to $2.25 \mathrm{~mm}$ ) is $32 \%$, in stage IV (2.26 to $3 \mathrm{~mm}$ ) is $69 \%$ and in stage $\mathrm{V}(>3 \mathrm{~mm})$ disease is $84 \% .5$

According to Clark, the percentage of patients with relapses or metastasis in postoperative period of five years, in stage I of disease is $0 \%$, in stage II is $4 \%$, in stage III is $33 \%$, in stage IV is $61 \%$ and in stage V of disease is $78 \% .5$

In a five-year period from surgery in 4 (12.5\%) of our respondents in group A had recurrent of disease, and all were operated for melanoma with approximate thickness of $2 \mathrm{~mm}$ (stage III of disease).

In group $\mathrm{B}$, during the five-year period there were $13(40.7 \%)$ of disease recurrent and majority after surgery of melanoma, thickness about $3 \mathrm{~mm}$ (IV and $\mathrm{V}$ disease stages).

We operated one respondent for melanoma on the back in group B, with radical axillary dissection. $\mathrm{PH}$ findings showed the stage of melanoma: Clark V, Breslow V. This respondent has no signs of relapse of the disease, even after 7 years from operation.

Some of malignant pigmented lesions on the skin remain on surface and are relatively less aggressive. In fact, by the surface shape we can describe melanomas which tend to expand very little into epidermis with habit to remain high in corium, i.e., not expand into the more important layers below the intrapapillary extensions. Melanoma invasion of subcutaneous tissues usually means poor prognosis. Surgical excision of these lesions is not successful, as it is regularly delayed. 17-22

Surgical treatment of melanoma involves radical excision of $3-5 \mathrm{~cm}$ from lesion.23 However, since melanoma is extremely prone to dissemination6 local radical excision alone is not sufficient or it is "half the job".24-16

Our research has shown that the basic and imperative method of treating melanoma and further surgical local eradication of tumor, which include radical excision, an ex-tempore diagnosis, sentinel diagnosis and, if necessary dissection of related lymphatics. This of course applies to patients who are deemed operable in preoperative treatment.

From a total of $64(100 \%)$ of our respondents, during the five-year period 11 of them $\operatorname{died}(17.2 \%)$, that can be considered as a relatively small percentage of mortality compared to the data from the recent literature. 


\section{Conclusion}

Localization of tumors essentially determines the time when the respondents come to examination.

Melanoma on the back remains unnoticed for a long time, i.e. unrecognized changes in lesions compared to lesions on other anatomical regions, which is probably the reason for the greater waste of time and late diagnosis.

The most common location of melanoma in both groups is at the back therewith in group B position of melanoma on back is dominant.

\section{References}

1. Grin CM., Kopf AW., Welkovich B., Bart RS., Levenstein MJ. Accuracy in the clinical diagnosis of malignant melanoma. Arch Dermatol 1990;126:763-766.

2. Miller M., Ackerman AB. How accurate are dermatologists in the diagnosis of melanoma? Degree of accuracy and implications. Arch Dermatol 1992;128:559-560.

3. Wolf IH., Smolle J., Soyer HP., Kerl H. Sensitivity in the clinical diagnosis of malignant melanoma. Melanoma Res 1998;8:425-429.

4. Mayer J., Systematic review of the diagnostic accuracy of dermatoscopy in detecting malignant melanoma. Med J Aust 1997;167:206-210.

5. Lukić D. Tumori kože, Medicinski fakultet Banja Luka, 2010; 45-48.

6. Stolz W., Riemann A., Cognetta AB., et al. ABCD-rule of dermatoscopy: a new practical method for early recognition of malignant melanoma. Eur J Dermatol 1994;7:521-528.

7. Menzies SW., Ingvar C., McCarthy WH. A sensitivity and specificity analysis of the surface microscopy features of invasive melanoma. Melanoma Res 1996; 6:55-62.

8. Starz H., De Donno A., Balda B. The Augsberg experience: histological aspects and patient outcomes. Ann. Surg. Oncol. 2001; 8( 9), 48-51.

9. Andersen BL., Shapiro CL., Farrar WB., Crespin T., Wells-Digregorio S. Psychological responses to cancer recurrence. Cancer 2005;104:1540-7.

10. Pehamberger H., Steiner A., Wolff K. In vivo epiluminescence microscopy of pigmented skin lesions. I. Pattern analysis of pigmented skin lesions. J Am Acad Dermatol 1987;17:571-583.

11. Nowecki ZI., Rutlowski P., NasierowskaGuttmejer A., Ruka W. Sentinel lymph node biopsy in melanoma patients with clinically negative regional lymph nodes-one institutions experience. Melanoma Res. 2003; 13, 35-43.

12. Essner R., Bostick PJ., Glass EC., et al. Standardized probe-directed sentinel node dissection in melanoma. Surgery, 2000;127(1), 26-31.
Respondents in group B consulted the doctor 4-5 months later, because of melanoma position than the group A, which proved to be statistically significant.

There was found a statistically significant difference in terms of recurrence of the disease. Relapse was observed 3 times higher in group B.

Localization of melanoma significantly affects the outcome of treatment of disease. There was a statistically significant difference in survival of respondents per groups because the mortality rate in group B was almost 3 times higher.

13. Morton DL., Thompson JF., Cochran AJ. et al. ASCO annual meeting proceedings. J. Clin.Oncol. 2005;23, (16 Suppl. Part I of II).

14. Balch CM., Soong SJ., Atkins MB., Buzaid AC., Cascinelli N., Coit DG., et al. An evidence-based staging system for cutaneous melanoma. CA Cancer J Clin 2004;54: 131-149.

15. Kalady MF., White RR., Johnson JL., Tyler DS., Steigler HF. Thin melanomas: predictive lethal characteristics from a 30-year clinical experience. Ann Surg 2003;238: 528-537.

16. Pawlik TM., Ross MI., Thompson FJ., Eggermont AMM.,Gerschenwald JE. The risk of in-transit melanoma metastases depends on tumor biology and not the surgical approach to regional lymph nodes. J Clin Oncol 2005;23: 4588-4590.

17. Kang JC., Wanek LA., Essner R., Faries MB., Foshag LJ., Morton DL. Sentinel lymphadenectomy does not increase the incidence of in-transit metastases in primary melanoma. J Clin Oncol 2005;23:4764-70.

18. Essner R., Cochran AJ. Sentinel node biopsy: not only a staging tool? Recent Results Cancer Res. 2002; 160, 133-148.

19. Balch CM., Buzaid AC., Soong SJ., et al. Final version of the American Joint Committee on Cancer staging system for cutaneous melanoma. J Clin Oncol 2001;19: 3635-48.

20. Morton DL., Wen DR., Wong JH. et al. Technical details of intraoperative lymphatic mapping for early stage melanoma. Arch. Surg. 1992;127(4), 392-399 .

21. McMasters KM., Noyes RD., Reintgen DS. et al. Lessons learned from the sunbelt melanoma trial. J. Surg. Oncol, 2004; 86, 212-223.

22. Padgett JK., Hendrix JD Jr. Cutaneous malignancies and their management. Otolaryngol Clin North Am, 2001;34:523-553.

23. Morton DL., Cochran AJ., Thompson JF. et al. Sentinel node biopsy for early-stage melanoma accuracy and morbidity in MSLT-1, an international multicenter trial. Ann. Surg. 2005;242(3), 302-313. 
24. Pennington B.E., Leffe,D.J. Mohs micrographic surgery: Established uses and emerging trends. Oncology, Willston Park, Aug. 2005;19(9),1165-71.

25. Deo S.V., Hazarika S., Shukla N.K., Kumar S., Kar M., Samaiya A. Surgical management of skin cancers: Experience from a regional cancer centre in North India. Indian journal of cancer, 2005;42,( 3), 145-50.
26. Kammula US., Ghossein R., Bhattacharya S., Coit DG. Serial follow-up and the prognostic significance of reverse transcriptase-polymerase chain reaction-staged sentinel lymph nodes from melanoma patients. J. Clin. Oncol. 2004;22(19), 3989-3996. 